International Research Journal of Management, IT \& Social Sciences
Available online at https://sloap.org/journals/index.php/irjmis/
Vol. 8 No. 1, January 2021, pages: 60-69
$\begin{aligned} & \text { ISSN: 2395-7492 } \\ & \text { https://doi.org/10.21744/irjmis.v8n 1.1111 }\end{aligned}$

\title{
The Effectiveness of e-ID Card Services in Sub-District City North Ternate
}

\begin{tabular}{|c|c|}
\hline & $\begin{array}{r}\text { Abdulhalil Hi. Ibrahim } \\
\text { Saiful Deni }^{\mathrm{a}} \\
{ }^{\mathrm{b}} \\
\text { Syofyan Saraha }^{\mathrm{c}} \\
\text { Sofyan Bin Taher }^{\mathrm{d}} \\
\text { Marno Wance }^{\mathrm{e}}\end{array}$ \\
\hline Article history: & Abstract \\
\hline $\begin{array}{l}\text { Submitted: } 09 \text { October } 2020 \\
\text { Revised: } 18 \text { November } 2020 \\
\text { Accepted: } 27 \text { December } 2020\end{array}$ & $\begin{array}{l}\text { This research is a descriptive qualitative study to analyze or explain the } \\
\text { effectiveness of e-ID services in Ternate City District Office in improving the } \\
\text { handling of service of e-ID; study descriptive aimed to explain something the } \\
\text { object of research is relatively deep and focused on the object study. The } \\
\text { research results show that the implementation of e-ID services in the District } \\
\text { of North Ternate City began recording the mass until manually recording is }\end{array}$ \\
\hline $\begin{array}{l}\text { Keywords: } \\
\text { card services; } \\
\text { environmental organizations; } \\
\text { implementation services; } \\
\text { information technology; } \\
\text { motivation work; }\end{array}$ & $\begin{array}{l}\text { currently not implemented effectively. This can be proven by several indicators } \\
\text { of effectiveness measurement, namely the Achievement of Objectives in terms } \\
\text { of the time target has not been achieved. In terms of the final goal, which is the } \\
\text { concrete target of recording implementation for compulsory e-ID Card, only } \\
92.49 \% \text { have been recorded while the remaining } 7.51 \% \text { have not been } \\
\text { recorded. There is miscommunication between the sub-district government and } \\
\text { the civil registry office of Ternate City so that for now, all recordings have } \\
\text { been pulled in the civil registry office of Ternate City. }\end{array}$ \\
\hline
\end{tabular}

International research journal of management, IT and social sciences (C) 2021. This is an open access article under the CC BY-NC-ND license (https://creativecommons.org/licenses/by-nc-nd/4.0/).

Corresponding author:

Abdulhalil Hi. Ibrahim,

Pattimura University, Ambon, Indonesia.

Email address: marno.wance@fisip.unpatti.ac.id

\footnotetext{
${ }^{a}$ Muhammadiyah University of North Maluku, Indonesia

Muhammadiyah University of North Maluku, Indonesia

Muhammadiyah University of North Maluku, Indonesia

Muhammadiyah University of North Maluku, Indonesia

Pattimura University, Ambon, Indonesia
}

60 


\section{Introduction}

Rapid technological advances require agencies to keep abreast of technological developments. The rapid development of Information technology has led to a new revolution in transforming conventional work systems to the digital era. This change has also changed everyone's perspective in carrying out various activities, one of which is government agencies' activities. Thus, an agency needs an information system that supports the needs of government agencies in creating work efficiency and effectiveness and improving service delivery to the community (Martani \& Lubis, 1987; Aslan, 2019; Putra et al., 2020). By managing data online, the weaknesses of conventional data processing can be suppressed. Population Administration Information System itself provides many benefits, among others, the results of the calculation and management of statistical data can be used as material for formulating and refining policies, strategies and programs for the implementation and implementation of development in the areas of quality, quantity and population mobility, as well as other development interests (Indrajit, 2002; Aslan \& Hifza, 2020).

Matters like the ones mentioned above have been integrated into the form of electronic identity cards as one of the strategies that are expected to become the government's electronic pillars in providing increased development and development planning in the future. One major change that has emerged through e-ID is a population document that contains a security control system both from the administrative and information technology side based on the national population database. Residents are only allowed to have one Id Card listed as a National Identity Number, a single identity for each resident, and valid for life. The National Identity Number in the e-ID will later be used as the basis for issuing passports, driving licenses, taxpayer-identification numbers, insurance policies, certificates of land rights, and issuance of other identity documents. (Article 13 of Law Number. 2006 on Population Administration).

The e-ID program in Indonesia began in 2009 with the designation of four cities as national pilot projects. The four cities are Padang, Makassar, Yogyakarta, and Denpasar. While the Ministry of Home Affairs officially launched other districts in February 2011, the implementation was divided into two phases. The first phase of implementation began in 2011 and ended on 30 April 2012, covering 67 million people in 2348 sub-districts and 197 districts. Meanwhile, the second phase includes 105 million people spread across 300 other districts in Indonesia. Overall, by the end of 2012, it is targeted that at least 172 million people will already have e-ID and from the beginning to the end of 2013 the recording of population data will continue until all Indonesian citizens are required to have their ID recorded with their data.

Implementation of e-ID In North Maluku, since the first year the e-ID program was launched, in 2012, the mass recording was carried out simultaneously in 10 districts in the province of North Maluku and up to August 2014, the total recording that had been carried out was 468,557 The total number of ID compulsory people is 621,439 , so the remaining ID cards that have not been recorded are 152,882 people. If presented, $75 \%$ of ID obligors who have recorded e-ID in North Maluku Province, while those who have not recorded are 25\%. For Ternate City's area up to August 2014 with a population of 102,050 people and a mandatory e-ID of 58,286 people had been recorded as many as 48,436 people, so that the remaining ib e-ID that had not recorded was 9,850. The District of Ternate Utara is one of the Districts within the City of Ternate that runs ID-card recording services. The e-ID service in the District of North Ternate City is implemented simultaneously.

Services also arise due to the obligation as a form of implementation of an organization's processes. Where every organization, both government organizations, and private organizations, the service objectives have been determined simultaneously with the organization's formation. To explain the broader definition of service, the author follows the opinion of Steers, (1977) who states that: Service is essentially a series of activities because it is a series of processes. As a service process, it takes place regularly and continuously, covering all life people in society. A group of people carries out service to fulfill the interests of a group of other people in an organization or organization, both government and private (Hifza, 2020; Hifza et al., 2020). More firmly regarding the definition of service, Moenir (1982) expresses his views as follows: Service is any activity carried out by other parties aimed at fulfilling the interests of many people. Liang (1965), states that service is an action taken to meet the needs of others whose level of satisfaction can only be felt by those who serve and those who are served. Liang (1965), suggests that service is an activity carried out to fulfill, practice, and devote. Meanwhile, James (1986) provides a limitation that: Service is the process of using the mind, mind, five senses and limbs and or without aids done by someone to get something that is desired either in the form of Robbins (2002) defines public services are various activities that aim to meet the needs of society for goods and services (Robbins, 1994; Robbins et al., 2008; Robbins, 2013).

In simple terms, e-ID comes from the word electronic-ID, or Electronic Identity Card, or often abbreviated as eID. In more detail, according to the official e-ID website, an electronic ID is a population document containing a security control system from both an administrative and information technology side based on a national population

Ibrahim, A. H., Deni, S., Saraha, S., Taher, S. B., \& Wance, M. (2021). The effectiveness of e-ID card services in subdistrict city North Ternate. International Research Journal of Management, IT and Social Sciences, 8(1), 60-69. https://doi.org/10.21744/irjmis.v8n1.1111 
database. e-ID is an official government program, therefore in the implementation of e-ID has the following legal bases:

1) Law - Law of the Republic of Indonesia Number 23 the Year 2006 concerning Population Administration, explained that: "the population is only allowed to have one (1) ID card listed Population Identification Number. Single identity of each resident and valid for life n. No. in the e-ID will later be used as the basis for issuing passports, driving licenses, taxpayer-identification numbers, insurance policies, certificates of land rights, and issuance of other identity documents.

2) Presidential Regulation No. 26/2009 concerning Application of ID based on Population Identification

Number, which reads:

a) The IN-based ID contains a security code and an electronic record as a means of verification and validation of the population's identity data;

b) The electronic record as referred to in paragraph (1) contains the biodata, signature, passport photo, and handprint of the population concerned;

c) Records of all the fingerprints of the residents' hands are stored in the population database (3) Collecting all fingerprints of the hands of the residents as referred to in paragraph shall be carried out at the time of applying for an IN-based ID Card, provided that: For Indonesian citizens, this is done in the subdistrict; and foreigners who have a permanent residence permit at the implementing agency;

d) Recording of the resident's handprint contained in the ID card as referred to in paragraph (2) contains the index finger of the left hand and the index finger of the right hand of the population concerned;

e) Records of all fingerprints of the residents' hands as referred to in paragraph (3) can be accessed by interested parties following laws and regulations. a Ministerial Regulation regulates g. Further provisions regarding the procedure for fingerprint recording.

The use of smart cards for an e-ID card with a chip containing information on biodata, photos, signature images, and 2 right and left index fingerprints and biometric technology also supports high-security methods. Biometrics technology can identify the singular identity of the population from the results of recording the population data of the obligatory e-ID card so that it can produce a single identity of the population (unique and single IN) as the basis for making an accurate national population database and single identity data on the e-ID card. The use of biometrics technology in the e-ID card program can be divided into two parts; the process of deduplication test the singular identity of the population and the process of verifying the e-Id card owner.

In practice, the use of the e-ID card has proven to have weaknesses. For example, the owner's signature does not appear on the surface of the ID Card. The absence of a signature on the e-ID card has created separate cases for some people. For example, when making transactions with banking institutions, the e-ID card is not recognized because there is no signature display. There are several cases where e-ID cardholders cannot transact with the bank because they do not have a signature. The bank cannot read the signature printed on the chip because it does not have a card. Finally, the thee-Id cardholder was forced to ask for a recommendation from the Head of the Population and Civil Registry Service to convince the bank. Besides, the Minister of Home Affairs Gamawan Fauzi has submitted an official circular number. Number 471.13/1826/ SJ, the e-ID card is not allowed to be photocopied to avoid fatal errors related to reading using a card reader. The e-Id card is of course, different from the National ID-Card currently circulating. From the physical form, the basic ingredients of this ID card are very different from one another. The following is a detail of the difference between an e-ID card and a National ID card.

Table 1

Table of Differences between e-ID card and National ID card

\begin{tabular}{lllll}
\hline No & Type of ID card & Characteristics & Technology & Verification \\
\hline 1 & $\begin{array}{l}\text { ID card } \\
\text { National }\end{array}$ & $\begin{array}{l}\text { Photo printed on the card, } \\
\text { Signature, and } \\
\text { thumbprint, Computer printe } \\
\text { d data, National valid Not } \\
\text { easy to crumple }\end{array}$ & $\begin{array}{l}\text { Material made of plastic, } \\
\text { special serial number, ID } \\
\text { only, photo scanning and } \\
\text { signature }\end{array}$ & $\begin{array}{l}\text { Supervision and verification } \\
\text { of validation from the lowest } \\
\text { level block/street onwards }\end{array}$ \\
2 & E-ID Card & $\begin{array}{l}\text { Photo printed on the card, } \\
\text { data printed by computer, } \\
\text { national valid, can store }\end{array}$ & $\begin{array}{l}\text { Material made of PVC/PC, } \\
\text { There is a microchip to } \\
\text { store data, Biometrics }\end{array}$ & $\begin{array}{l}\text { Supervision and verification } \\
\text { of validation from the lowest } \\
\text { level of block/street }\end{array}$ \\
\hline
\end{tabular}


data, can be read and written

by the card reader data, Able to

accommodate personal

data needed in multi

applications onwards, Multi-

application, internationally

accepted, Non-

counterfeit, One man one

card, Very high level of

confidence in the validity of

the card

Source: Processed by the author

If achieved its objectives or goals as prescribed. This is according to Kurniawan (2005) opinion, which states that Effectiveness is a measurement in the sense of achieving predetermined goals. Meanwhile, Sutarto (1989) stated: Effectiveness is viewed from the point of view of achieving goals, where an organization's success must consider not only organizational goals but also self-defense mechanisms in pursuit of goals. Effectiveness is the ability to carry out tasks, functions rather than an organization or the like are not any pressure or tension between implementation. According to Ibrahim (2020), the public policy done through the process of planning that is already in the analysis is comprehensive. Furthermore, Steers (1977) argues that: Effectiveness is the range of efforts of a program as a system with certain resources and means to fulfill its goals and objectives without crippling these means and resources and without putting undue pressure on its implementation. Furthermore, Agung Kumiawan, in his book Transformation of Public Services defines effectiveness as follows: Effectiveness is the ability to carry out tasks, functions rather than an organization or the like where there is no pressure or tension between its implementations (Kurniawan, 2005). Model accountability of services public who respond to the people's local's demands should be expected to resolve the various problems of practical which regulate the procedure, the determination of cost, time and mechanism of complaints and the establishment of facilities services (Herizal et al., 2020).

\section{Materials and Methods}

This research is descriptive qualitative research that aims to obtain a general understanding of social reality from the participants' perspective, which can be obtained after a social analysis is the focus of the research. Meleong (2008) says that a qualitative approach is expected to be able to produce an in-depth description of speech, writing, or observable behavior of an individual, group or community and/or a certain organization in a certain location that is studied from a complete, comprehensive point of view. and holistic. One of the reasons for using a qualitative approach in this research is based on the explanation of Guba \& Lincoln (1988), that qualitative research or naturalistic inquiry is a research method that is intended to understand actuality, social reality, and existing human perceptions. Referring also to Lisa Harison's (2009) view, qualitative research or research conducted on the situation naturalistic field of research that is "natural" or reasonable is, without being manipulated and regulated through experimentation.

\section{Results and Discussions}

\section{E-ID Card Service Effectiveness In North Ternate City District}

The government implements e-Government, which aims to create a democratic, transparent, clean, fair, accountable, responsible, responsive, effective, and efficient government. e-Government takes advantage of advances in communication and information in various aspects of life and increases competitiveness with other countries. As stated in Law Number 11 of 2008 concerning Information and Electronic Transactions. e-Government implements an electronic-based government system to provide convenience, increase transparency, increase interaction with the community, and increase public participation. Based on this explanation, one of the e-Government implementation applications in public services using technology and information that is currently being implemented in the government sector is the e-ID Card (Electronic Identity Card). Indonesia, with a large population, needs accurate population data, for this, the government has created a program called e-ID Card. E-ID Card is a new, surefire way to be taken by the government by building a national population database to provide identity to the community using the existing biometric system so that each e-ID Card owner can be connected to a national database so that every resident only needs one ID card

Ibrahim, A. H., Deni, S., Saraha, S., Taher, S. B., \& Wance, M. (2021). The effectiveness of e-ID card services in subdistrict city North Ternate. International Research Journal of Management, IT and Social Sciences, 8(1), 60-69. https://doi.org/10.21744/irjmis.v8n1.1111 
Identity Card is an official identity of the resident as proof of identity issued by the Ministry of Home Affairs, which is valid throughout the Republic of Indonesia's territory. This card is mandatory for Indonesian citizens and foreign citizens who have a Permanent Stay Permit (PSP) who are 17 years old or have been married or have been married. Children of parents of foreign citizens who have PSP and are 17 years old are also required to have an ID Card. According to laws and regulations, namely Law Number 24 of 2013 concerning Amendments to Law Number 23 of 2006 concerning Population Administration article, 1 point 14 that Electronic Identity Cards are Identity Cards equipped with a chip which is the official identity of the population as proof of identity issued by the Implementing Agency. According to the prevailing laws and regulations, Electronic Identity Card is a computerized Identity Card computerized and equipped with a chip that functions to store bio, fingerprints, and signatures.

E-ID Card is one of the national programs that must be implemented by the government in every region because the implementation of the e-ID card is seen as very relevant to the government's plan in creating quality and technologybased public services to obtain more precise and accurate population data results (Garrick et al., 2009; Moullin et al., 2016). E-ID Card is a program that has been created by the government through the Ministry of Home Affairs (Ministry of Home Affairs) since 2006 but was only established and implemented in 2009 based on laws and presidential regulations. The Department of Population and Civil Registration of Ternate City and the North Ternate District Government of Ternate City has an important role in the success of the e-ID Card which is under the program that has been launched by the central government of the Republic of Indonesia, in its application the Department of Population and Civil Registration and the Government of North Ternate District is expected to be able to maximize its potential. exist and work well together (Rössler, 2008; Arora, 2008). With geographic conditions that can be reached and the lack of facilities and infrastructure in the North Ternate District area, of course, the e-ID card service must be implemented carefully so that later it can take place effectively.

Effectiveness is the ability to carry out tasks, functions (operating program activities or missions) of an organization or the like where there is no pressure or tension between its implementations. It can be concluded that effectiveness is a measure that states how far the targets (quantity, quality, and time) have been achieved by management, where these targets have been determined in advance. Efforts to evaluate the running of an organization can be made through the concept of effectiveness. This concept is one of the factors in determining whether it is necessary to make significant changes to the organization's form and management. In this case, the organizational objectives' effectiveness through the utilization of its resources efficiently determines the inputs, process, and output. In this case, the definition of resources includes the availability of personnel, facilities, and infrastructure, and the methods and models used. An activity is said to be efficient if it is carried out correctly and under procedures. In contrast, it is said to be effective if the activity is carried out correctly and provides useful results.

Achievement is the overall effort to achieve goals that must be viewed as a process consisting of several factors: timeframe and objectives which are concrete targets. In connection with the target time for the implementation of the e-ID card service in the District of North Ternate City and based on the results of the researcher interview with the Head of the Ternate City Civil registry Office, Rukmini A. Rahman, stated as follows:

From the target time for mass recording services for people who are required to have ID Card until now, at the end of 2019, not all of the people who are required to have an ID Card in North Ternate District have been served considering that several obstacles in the field such as other supporting infrastructure are still minimal so that it needs improvement in the field gradually. (Interview, February 13, 2020).

The results of the interview above, after the researcher proved it with field observations, namely the North Ternate District, which consists of 14 villages, it was found that it was true that recording facilities and infrastructure often experienced disruption, including the internet network. The same information was also provided by the City of North Ternate regarding the implementation period of the e-ID card in the District of North Ternate City. When the researcher interviewed the Head of North Ternate Sub-district, Zulkifli, it was said that as:

From the time target set, which is until the end of 2019, the residents who are required to have an ID card in North Ternate District have been recorded for the first phase through mass recording, but the target time has not been fulfilled considering several things including that this program is a government program which certainly requires readiness. Human Resources, supporting facilities, and infrastructure that are mature. However, even though it did not meet the target time in 2019, it can be continued with manual recording, which continues until all the mandatory ID cards for North Ternate District can be served". (interview, 11 February 2020).

From this information, it can be seen that even though the mass recording that has been carried out has ended, the implementation of recording ID card manually is still carried out until all ID card obligors have been served in the 
district of North Ternate City. This is also reinforced by the following interviews at the Head of North Ternate City, who are as follows: The service process is still being carried out until now so that if there are people who have not done the recording, they can come to the sub-district office to do the recording and I also say that for now the e-ID card service is not only carried out at the sub-district office but with the policy of the government. Ternate sub-district and civil registry office City coordinate to open several spot points in the villages so that that community coverage can be fulfilled in recording and making e-ID card activities; residents in sub-districts can also provide services to the Ternate City Civil Registry Office because the printing process can be done at the City civil registry Office Ternate. (interview, 11 February 2020).

The description of the interview above provides information that the implementation of e-ID Card making is still ongoing and very easy to access by the community; people in the North Ternate City area have to choose whether through the North Ternate Sub-District Office, at a spot point, or directly to the Population and Civil Registry Office Ternate City. This illustration can be said that the effectiveness can be guaranteed, it only depends on how the community responds.

\section{Dimensions Affecting the Effectiveness of e-ID card Services in the District of North Ternate City Motivation}

Work motivation, namely individual work motivation caused by work changes. According to the Head of e-ID Card service officers in North Ternate City Sub-district Office, according to the Head of the Government Section of the North Ternate City Sub-district Office, he said that the motivation of e-ID card service officers is good and eager to succeed in this program, according to the following interview results: Our motivation from the time of mass recording to manual recording services is very high. This is also a boost and motivation to make this program a success and also encouragement from our leaders to be able to succeed in this program even with limited conditions". Stay enthusiastic because this is a national program. The enthusiasm of officers and operators of e-ID Card recording is proven through collectively carrying out service functions to the community in stages by going to the field to provide education about e-ID card ownership. (interview, 15 February 2020 ).

The Head of the Government section above shows that the e-ID card service officer at the North Ternate City Subdistrict Office has high motivation because success in carrying out their duties is their satisfaction. This is what is meant by the spirit of devotion to the b bureaucracy of the Government (Putra \& Dewi, 2019). In connection with this matter, one of the thee-ID Card service operators who was also an informant said; "I feel compelled to provide understanding and service to people who don't understand the meaning of using ID card and make it successful in its implementation. On the other hand, other operator officers also expressed the same thing related to motivation at the time of implementation; this was revealed by the results of an interview with one of the staff of the North Ternate City sub-district office who also carried out perfect e-ID Card service activities, as follows. Based on the aggregate data of the Ternate City Civil registry Office in 2019, special services for recording e-ID cards range from \pm 10 to 25 people every working day. (Interview, 16 February 2020 ).

The results of this interview show that at the time of implementing the e-ID card service related to the officers' motivation, it did not show anything that was hindering. The motivation and enthusiasm of the implementing officers, both Operators, and staff of the North Ternate City Sub-district Office in helping this activity, were a strength separately in implementing the e-ID Card services, especially in the District of North Ternate City (Lam \& Gurland, 2008; Dwivedula \& Bredillet, 2010; Lundberg et al., 2009). Work motivation is good; when the researcher asks whether there are any obstacles or obstacles in carrying out e-ID card recording services, one of the operators said that, are as follows: The obstacles that have been faced by officers are the lack of supporting facilities such as a waiting room and chairs so that people have to wait a long time, and the internet network is sometimes slow, etc. However, the implementation of the e-ID card service continues. (Interview, 15 February 2020). From the interview excerpt above, it can be stated that the supporting facilities for e-ID card recording services, limited waiting rooms, and Internet facilities often experience disruption, but services are still carried out properly.

\section{Workability}

Workability, namely the ability of individuals to face their work, whether it is related to understanding their field of work or other expertise to support the e-ID card service. In this case, expertise focuses on e-ID card operators who are the main service personnel because they are related to the use and mastery of electronic devices. In connection with this matter, based on the results of an interview with a key informant who is also the Head of the Government Section

Ibrahim, A. H., Deni, S., Saraha, S., Taher, S. B., \& Wance, M. (2021). The effectiveness of e-ID card services in subdistrict city North Ternate. International Research Journal of Management, IT and Social Sciences, 8(1), 60-69. https://doi.org/10.21744/irjmis.v8n1.1111 
at the North Ternate City Sub-district Office, he said that the operator had been provided several times with the implementation of technical guidance as quoted from the interview, as follows: For service personnel related to the abilities, especially operators, they have been provided initially with several times the implementation of technical guidance for operators. At that time, technological assistance was held at the Vellya Hotel, Ternate City, and there were also other technology training being held, but the exact location I forgot where. (Interview, 15 February 2020).

The interview results above provide information that technical or operational guidance in using the e-ID card recording device is necessary for operator officers to know; this is done because it requires special skills. It is known that the operator officers have conducted several training or technical guidance. When the researcher confirmed with the recording operator officer at the Head Office of the City of North Ternate, Ratno Kamah, the informant said, was as follows: "Sub-district officers who have previously been equipped with Bimtek accompanied by officers from the civil registry office service jointly carry out the e-ID card service. There are no special requirements; as long as they can operate a computer and use the internet network, they feel that they meet the criteria for recording implementation. (Interview, 15 February 2020).

The interview narrative above provides information to become an e-ID card recording operator, and there are no special requirements. The most important thing is to operate a computer, surf the internet and the rest we follow technical guidance. Another operator statement also said that in general and procedurally, we had followed Technical Guidance. During our implementation, the operator had carried out activities well, but sometimes there were often errors in recording activities. (Interview, 15 February 2020). From the interview results above, the researcher can interpret that in principle, the operators can work because they have been provided with technical guidance. Still, the operators have not fully mastered technical problems to have fatal consequences to the recording results, such as using the same eye iris on several people can cause only one person whose data is received. In contrast, the others have personal data that is corrupted because the data is duplicated.

\section{Work Atmosphere}

Work atmosphere, namely the organizational atmosphere of the relationship between individuals in the North Ternate City Sub-district office during the e-ID card service process. To find out this, the researcher interviewed the Head of the Government section, who said: The working atmosphere between individuals in the office is good. This is because we always have the principle that in one office is a family that we always have to maintain both communication and relationships at work. (interview, 13 February 2020).

Further regarding the Working Atmosphere One operator who was also an informant briefly but clearly stated: The relationship is good, and there is often good cooperation. Thankfully, our officers remain professional and patient in serving the community both in making e-ID card recordings and carrying out civil registration. Solidarity is necessary for the work team not to be interpreted negatively by the community." (interview, 13 February 2020). This information was followed by the results of interviews with other operators who also conveyed the following interview results: "The working relationship as long as the service goes well, the two of us operators and our other friends are very compact, and our leadership is very harmonious in carrying out this service." ( interview, 13 February 2020 ). The interview above shows that the working atmosphere built in North Ternate City's sub-district office during the e-ID card service is perfect because they realize that with togetherness and a harmonious relationship, it can become a common force in carrying out their duties.

\section{Work environment}

The work environment is an environment outside the organization that influences individual work. A work environment is a place where people work or a place to do work. The work environment needs special attention because it is there that can determine the production results that will be obtained. A safe and comfortable environment will make work easier to do and get good results that are expected by an institution. Schultz (2006), according to both of them, the work environment is a condition that is related to the characteristics of the place where the work is carried out on the behavior and attitudes given by workers where it is related to the process of various psychological changes caused by this. Experienced at work or in certain conditions that need more attention by the organization which can give work boredom, always monotonous and work fatigue.

One of these factors, if it is related to environmental conditions outside the organization of the District of North Ternate City, a condition is found in which the cat as a leader always gives motivation and enthusiasm even though we are outside the office, the cat constantly does not expect anything but is always excited, as expressed when The 
researcher interviewed the Camat, Mr. Zulkifli, SE, as follows: With the limitations of North Ternate City sub-district employees, I always provide motivation. Hopefully, they can provide the best things related to public services, especially e-ID Card services. (Interview, 12 February 2020). From the description of the interview above, it can provide information that a good environment is related to e-ID card recording services. The Camat as a leader at the sub-district level always creates a good enough working environment a comfortable work environment is built and always inspires for service. This was confirmed by the community's opinion, who was also an informant for thee-ID card Recording Operator, namely Ibrahim Hadi, he said as follows. The motivation of a leader of the North Ternate sub-district government is related to public service serving wholeheartedly and unconditionally because we are also part of the community. (Interview, February 13, 2020). The interview narrative above provides information that the atmosphere of the work environment is always awakened by the Head of the North Ternate Sub-district's activeness, who often says that you should do your service properly because the service users, namely the community, are part of us.

\section{Conclusion}

That the implementation of e-ID card services in the District of Ternate Utara, which started from mass recording to manual recording, has not been implemented effectively. This can be proven by several indicators of effectiveness measurement, namely the achievement of objectives in terms of the time target has not been achieved. In terms of the final goal, which is the concrete target of recording implementation for a compulsory e-ID card, only $92.49 \%$ have recorded. In comparison, the remaining $7.51 \%$ have not been recorded. There is miscommunication between the subdistrict government and the civil registry office of Ternate City so that for now, all recordings have been pulled in the civil registry office of Ternate City. In terms of integration, it has been carried out well to the community in the form of socialization, but on the consensus side and communication with other organizations has not been maximally implemented. In contrast, in terms of adaptation, organizations' ability to adapt to the work environment is quite good, where the leadership is very concerned about providing motivation. The dimensions that hinder the implementation of the effectiveness of e-ID card services in the District of North Ternate City, some of which have been carried out properly, including Work Motivation, Work atmosphere, Work Procedures While other dimensions that have not been implemented optimally affect the effectiveness of e-ID card services, namely: Workability, work environment equipment, and facilities.

That the implementation of e-ID card services in the District of Ternate Utara, which started from mass recording to manual recording, has not been implemented effectively. This can be proven by several indicators of effectiveness measurement, namely the Achievement of Objectives in terms of the time target has not been achieved. In terms of the final goal, which is the concrete target of recording implementation for the compulsory e-ID cards, only $92.49 \%$ have recorded. In comparison, the remaining $7.51 \%$ have not been recorded. There is miscommunication between the subdistrict government and the civil registry office of Ternate City so that for now, all recordings have been pulled in the civil registry office of Ternate City. In terms of integration, it has been carried out well to the community in the form of socialization, but on the consensus side and communication with other organizations has not been maximally implemented. In contrast, in terms of adaptation, organizations' ability to adapt to the work environment is quite good, where the leadership is very concerned about providing motivation. The dimensions that hinder the implementation of the effectiveness of e-ID card services in the District of North Ternate City, some of which have been carried out properly, including Work Motivation, Work atmosphere, Work Procedures While other dimensions that have not been implemented optimally affect the effectiveness of e-ID Card services, namely: workability, work environment equipment, and facilities.

Ibrahim, A. H., Deni, S., Saraha, S., Taher, S. B., \& Wance, M. (2021). The effectiveness of e-ID card services in subdistrict city North Ternate. International Research Journal of Management, IT and Social Sciences, 8(1), 60-69. https://doi.org/10.21744/irjmis.v8n1.1111 
Conflict of interest statement

The authors declared that they have no competing interests.

Statement of authorship

The authors have a responsibility for the conception and design of the study. The authors have approved the final article.

\section{Acknowledgments}

Thank you for us to convey to the Director of Post Graduate magister Science Administration of the University of Muhammadiyah North Maluku, which have provided input and support to research this can be carried out until the finish. 


\section{References}

Arora, S. (2008). National e-ID card schemes: A European overview. Information Security Technical Report, 13(2), 46-53. https://doi.org/10.1016/j.istr.2008.08.002

Aslan, A. (2019). Peran Pola Asuh Orangtua di Era Digital. Jurnal Studia Insania, 7(1), 20-34.

Aslan, A., \& Hifza, H. (2020). The Community Of Temajuk Border Education Values Paradigm On The School. International Journal of Humanities, Religion and Social Science, 4(1).

Dwivedula, R., \& Bredillet, C. N. (2010). Profiling work motivation of project workers. International Journal of Project Management, 28(2), 158-165. https://doi.org/10.1016/j.ijproman.2009.09.001

Garrick, D., Siebentritt, M. A., Aylward, B., Bauer, C. J., \& Purkey, A. (2009). Water markets and freshwater ecosystem services: Policy reform and implementation in the Columbia and Murray-Darling Basins. Ecological Economics, 69(2), 366-379. https://doi.org/10.1016/j.ecolecon.2009.08.004

Guba, E. G., \& Lincoln, Y. S. (1988). Do inquiry paradigms imply inquiry methodologies. Qualitative approaches to evaluation in education, 89-115.

Herizal, H., Mukhrijal, M., \& Wance, M. (2020). Pendekatan Akuntabilitas Pelayanan Publik Dalam Mengikuti Perubahan Paradigma Baru Administrasi Publik. Journal of Governance and Social Policy, 1(1).

Hifza, A. (2020). The Model of Competitive Advantage Development in Private Islamic Education Institutions. In BASA 2019: Proceedings of the Third International Seminar on Recent Language, Literature, and Local Culture Studies, BASA, 20-21 September 2019, Surakarta, Central Java, Indonesia (p. 205). European Alliance for Innovation.

Hifza, J., Palapa, A., \& Maskur, A. (2020). The Strategic Foundation for Competitive Excellent Development in Integrated Islamic Primary Schools in Indonesia.

Ibrahim, N. K. (2020). Epidemiologic surveillance for controlling Covid-19 pandemic: challenges and implications. Journal of infection and public health.

Indrajit, R. E. (2002). Electronic government: strategi pembangunan dan pengembangan sistem pelayanan publik berbasis teknologi digital. Andi.

James, A. (1986). Sovereign statehood: The basis of international society (No. 2). Taylor \& Francis.

Kurniawan, A. (2005). Transformasi pelayanan publik. Pembaruan.

Lam, C. F., \& Gurland, S. T. (2008). Self-determined work motivation predicts job outcomes, but what predicts selfdetermined work motivation?. Journal of research in personality, 42(4), 1109-1115. https://doi.org/10.1016/j.jrp.2008.02.002

Liang, G. (1965). Ilmu administrasi: Pengertian, kedudukan dan perintjian. Pertjetakan Republik Indonesia.

Lundberg, C., Gudmundson, A., \& Andersson, T. D. (2009). Herzberg's Two-Factor Theory of work motivation tested empirically on seasonal workers in hospitality and tourism. Tourism management, 30(6), 890-899. https://doi.org/10.1016/j.tourman.2008.12.003

Martani \& Lubis. (1987). Manajemen Modem. Rineka Cipta.

Meleong, L. J. (2008). Metode Penelitian Kualitatif. Remaja Rosdakarya.

Moullin, J. C., Sabater-Hernández, D., \& Benrimoj, S. I. (2016). Model for the evaluation of implementation programs and professional pharmacy services. Research in Social and Administrative Pharmacy, 12(3), 515-522. https://doi.org/10.1016/j.sapharm.2015.08.003

Putra, G. N. S., \& Dewi, I. G. A. M. (2019). Effect of transformational leadership and organizational culture on employee performance mediated by job motivation. International research journal of management, IT and social sciences, 6(6), 118-127.

Putra, P., Mizani, H., Basir, A., Muflihin, A., \& Aslan, A. (2020). The Relevancy on Education Release Revolution 4.0 in Islamic Basic Education Perspective in Indonesia (An Analysis Study of Paulo Freire's Thought). Test Engineering \& Management, 83, 10256-10263.

Robbins Stephen, P., \& Judge, T. A. (2008). Perilaku Organisasi. Jakarta: Salemba Empat.

Robbins, S. (2013). Organizational Behavior (Arab World Edition). Pearson Education.

Robbins, S. P. (1994). Teori Organisasi: Struktur. Desain dan Aplikasi, Terjemahan Jusuf Udaya, PT Arcan, Jakarta.

Robbins, S. P. (2002). Prinsip-prinsip perilaku organisasi. Jakarta: Erlangga.

Rössler, T. (2008). Giving an interoperable e-ID solution: Using foreign e-IDs in Austrian e-Government. Computer Law \& Security Review, 24(5), 447-453. https://doi.org/10.1016/j.clsr.2008.07.006

Schultz, W. (2006). Behavioral theories and the neurophysiology of reward. Annu. Rev. Psychol., 57, 87-115.

Steers, R. M. (1977). Organizational effectiveness: A behavioral view. Goodyear Pub. Co.

Sutarto. (1989). Dasar-dasar kepemimpinan administrasi. Gadjah Mada University Press.

Ibrahim, A. H., Deni, S., Saraha, S., Taher, S. B., \& Wance, M. (2021). The effectiveness of e-ID card services in subdistrict city North Ternate. International Research Journal of Management, IT and Social Sciences, 8(1), 60-69. https://doi.org/10.21744/irjmis.v8n1.1111 